\title{
Regional Development Model Based on Organic Production of Nopal
}

\author{
Tavera Cortes María Elena1, Escamilla García Pablo Emilio², Alvarado Raya Horacio3, \\ Salinas Callejas Edmar ${ }^{4}$, Galicia Villanueva Silvia ${ }^{5}$ \\ ${ }^{1}$ Department of Graduate Studies and Research, Interdisciplinary Professional Unit of Engineering and Social \\ and Administrative Sciences, National Polytechnic Institute, Mexico City, Mexico \\ ${ }^{2}$ Department of Management of Projects, School of Mechanical Aerospace and Civil Engineering, The University \\ of Manchester, Manchester, UK \\ ${ }^{3}$ Department of Crop Sciences, Chapingo Autonomous University, Chapingo, Mexico \\ ${ }^{4}$ Department of Economy, Metropolitan Autonomous University Campus Azcapotzalco, Mexico City, Mexico \\ ${ }^{5}$ Department of Graduate Studies and Research, Superior College of Commerce and Administration Campus \\ Tepepan, National Polytechnic Institute, Mexico City, Mexico \\ Email: mtavera@ipn.mx, peeg85@gmail.com, horacio alvarado@hotmail.com, edmar01@yahoo.com, \\ sgaliciav@ipn.mx
}

Received 27 January 2014; revised 27 February 2014; accepted 6 March 2014

Copyright (C) 2014 by authors and Scientific Research Publishing Inc.

This work is licensed under the Creative Commons Attribution International License (CC BY).

http://creativecommons.org/licenses/by/4.0/

(c) (i) Open Access

\section{Abstract}

The compost production has been poorly explored in the agricultural areas of Mexico City. Farmers tend to use fresh manure as fertilizer on soil cultivation. The borough of Milpa Alta, as the main nopal producer in Mexico, requires a high amount of fertilizers to guarantee the fulfillment of yields and times of cultivation. Nevertheless the wide use of manure as only fertilizer implies several negative aspects not only for the crop but also for the environment. The compost is presented as a feasible option to improve the quality of crops and also to diminish the production cost. Compost has features and benefits that are directly reflected in the decrease of costs against the economic and conservation costs emerged with the use of fresh manure. The present research aims to evaluate the alternative use of harmless compost with quality to be used in agriculture. It was carried out through an analysis in an experimental plant built exclusively for the project. The main goal is to demonstrate the cost reduction in the nopal production in Milpa Alta by using compost instead of fresh manure.

\section{Keywords}

Compost; Nopal; Manure; Fertilizer; Agriculture 


\section{Introduction}

This paper presents the design of a regional development model based on organic production of nopal, as an alternative for small producers. The process would be versatile in adapting to different local microclimates. The design of the model is based on the experience of research into the production of nopal in a borough of Mexico City between 2006 and 2012. The town of San Lorenzo Tlacoyucan in the borough of Milpa Alta was selected due to conditions which were more conducive to research.

The borough of Milpa Alta has been one of the most important regions in the production of nopal in Mexico. Between 1984 and 2004 it was the main production region of nopal, however, due to several factors, it was displaced from its supremacy by the State of Morelos, particularly by the adjoining municipality of Tlalnepantla. From 2010, several changes in the production of nopal started and Milpa Alta recovered the lead in production. This aspect has been addressed in other research works already published.

In the field that research conducted between 2007 and 2008, four production methods of Nopal were identified-two methods of opencast production and two methods of production in tunnel which are subdivided into other two specificities-backyard cultivation and open-field cultivation.

The backyard growing is done on land around the houses of the producers; such areas are terrains ranging from 300 to 2000 meters. Until 2004, the opencast production dominated. Little by little the growing using backyard tunnel has been used. The field growing is carried out in terrains ranging from 3000 - 10,000 meters; however extensions of 5000 meters predominate. The growing is effectuated mainly in tunnels or greenhouses. The use of tunnels is the production technique which has considerably advanced in recent years.

For the design of this work, the fundamental aspect is not only the backyard production or in open field that combines the specificities of opencast and tunnel in areas ranging from 300 to 1000 meters, but also production methods which use organic products to fertilize and fumigate the soil, such as compost.

\section{Organic Agriculture}

Agriculture was originally organic, the art of taming and cultivating plants to generate food is very old, archaeologists have found the remains of the earliest agricultural production in Mesopotamia, (Currently Iraq, Iran and Syria), which go back 8000 to 7000 years BC. Agriculture in America began 3000 years BC and in China, Egypt and India dates back to 6000 - 5000 years BC [1].

These findings show that the human species invented agriculture in several places in the planet over a period of 5000 years, between 8000 and 3000 BC. Therefore the invention of agriculture involved an economic, social, political and cultural revolution, called by experts as the Neolithic revolution [2]. Human societies moved from nomadic life to settled life characterized by gathering, hunting, fishing and also agricultural production, building fortified villages that eventually became agro-artisanal and commercial cities.

In this long process, in addition to learn to identify the varieties of edible plants, the use of seeds, the production scale, patterns of diversified farming, the human species also learned to fertilize the soil and to combat pests with organic materials. Hence two methods were created; the method of fertilization with manure and method of diversified cropping patterns.

It was until recent times when farming ceased to be predominantly organic, almost until the twentieth century with the invention of inorganic fertilizers and fungicides. Population growth, the application of technical innovation in agriculture, the model of large-scale monocultures with high yields, resulted in the need to produce inputs that elevate the performance of crops per area, allowing greater planting density and shorter production cycles, to raise considerably the volume of the product.

In this way, the use of organic inputs was abandoned. Such organic materials had less impact on performance, covering smaller cultivation surfaces and representing some disadvantages in their application. They were usually organic inputs generated and empirically applied on crops.

The present work aims to analyze the advantages of organic materials in the organic and competitive production of small producers which impact positively on the conservation of the environment, in relation to natural fertilizer such as raw manure from bovine and chemical fertilizer.

\section{Characteristics and Properties of Manure as a Natural Fertilizer}

Manure is a valuable fertilizer used in any type of plot and used for centuries to address the need for nutrients needed for the crop development. However, their use and application has declined considerably in the last 50 
years due to:

1) The agricultural specialization to the increase the separation of agricultural production;

2) The cost of transportation;

3) The large volume of material and its low content of nutrients;

4) The increase of the availability of synthetic fertilizers of high analysis;

5) The high price per unit of nutrients compared to other fertilizers.

Hence, the abuse in the use of manure carries environmental risks. The control in the application is a complex process that, if it is not carried out correctly, could result in damage to agricultural production. The application of manure at rates that are too low can cause nutrient deficiencies and low yields. On the other hand, a dose too high can lead to the leaching of nitrates, the contribution of phosphorus, the acceleration of eutrophication of water bodies, and excessive vegetative growth of some crops.

The nutrient content of manure varies depending not only on: the type of animal but also the packaging, storage and processing. Although in the literature it is possible to find different tables with different nutrient content of manure types, experts in the matter [3]-[7] recommend that before being widely used, the manure should be analyzed by laboratory testing in order to determinate the specific characteristics, content of nutrients and moisture. With this it is possible to determinate whether it is feasible to use manure according to the type of crop. A laboratory analysis to determine the nutrient content must provide accurate data on: total nitrogen (N), ammonium $\left(\mathrm{NH}_{4}^{+}\right)$, phosphorus pentoxide $\left(\mathrm{P}_{2} \mathrm{O}_{5}\right)$ and potassium oxide $\left(\mathrm{K}_{2} \mathrm{O}\right)$.

The use of fresh manure in excess leads to salt accumulation and losses by leaching, in the same way, fresh manure can contain high amounts of weed seeds which can cause weed problem. Additionally, several pathogens including $E$. coli ${ }^{1}$ may be present in fresh manure and can cause severe gastrointestinal diseases. In contrast to all previously described, compost, due to its low moisture content, considerably reduces volume and weight, thereby transportation costs are reduced. Given its versatility, the handling of compost involves a simpler and more practical application in different surfaces.

The heat generated in the composting process reduces pathogens given the temperatures ranging from 150 to $175^{\circ} \mathrm{F}$ and the water content is reduced between $10 \%$ and $12 \%$ or less. Energy costs required to process fresh manure are significantly higher in contrast to the zero cost of self-heating generated by microbial respiration during the composting process. Note that compost made without strict process control can increase ammonia volatilization and reduce total content of nitrogen, in the same way, the material partially composted, produced without proper temperature control is not as biologically active as the mature compost. Therefore it is necessary to establish a composting process controlled and monitored to ensure the biological processes and thus the final product can provide all its properties and nutrients to the soil and crops as fertilizer. Among the main benefits of using compost in agricultural crop, the following are listed [8]:

1) Promotes aeration and moisture retention;

2) Together with clay, fosters formation of more stable aggregates;

3) In sandy soils helps water retention;

4) Improves soil structure;

5) Enables water absorption which is an erosion prevention agent;

6) Promotes the storage of nutrients and their availability to plants;

7) Provides an environment where countless microorganisms operate, some process the waste into humus, and others process humus to produce aliment;

8) Promotes the absorption of sunlight due to its dark colour, therefore the soil temperature in certain seasons;

9) Reduces or eliminates the need for fertilizers of chemical synthesis and moderates the temperature of the solid.

Other benefits can be appreciated in terms of the contribution they have in other aspects such as the fight against pollution (breaks down toxic substances, holds heavy materials, cleans polluted air) landscape restoration (helps reforestation, restores natural habitats, recovers mining and quarrying areas, restores damaged wetlands, prevents erosion and dust storms, reduces the production of methane from landfills, reduces or transforms organic matter and sewage sludge), saving money (reduces need for water, fertilizers and pesticides, can be marketed as a product, extends the life of landfills by reducing inputs of organic material, can be used for the

${ }^{1}$ Escherichia coli (commonly abbreviated E. coli) is a Gram-negative, rod-shaped bacterium that is commonly found in the large intestines of warm-blooded animals (endothermic). Most strains of E. coli are harmless, but some serotypes can cause serious intoxications in humans, and are occasionally responsible for remove of products due to food contamination. 
restoration of degraded soils) and pathogen control (eliminates microorganisms and pathogens, removes the seeds of weeds, eliminates stores of pathogens and parasites present in vegetable crop residues) [9].

Within the compost production in the Borough of Milpa Alta, fresh manure has been used as the main fertilizer in agricultural soils and plots. Its widespread use implies not only higher production costs in contrast to the use of compost but also environmental implications with a high maintenance cost. Production cycles in the region are inflexible given the environmental and meteorological characteristics of the area. Thus, the tight schedules for planting, growing and harvesting the crop, impede a clearance within work cycles to give proper treatment to the soil and to the manure used. In agricultural products for human consumption (as nopal) fresh manure should be applied on clean soil where the crop will be harvested at least three months before planting , and must pass four months between the application and the root crop and the crop portion that comes into contact with the ground. Under no circumstances, a superficial application must be performed. Such conditions are unfulfilled in most of the plots of nopal in Milpa Alta, so in the first instance, crop harmless is compromised.

\section{Compost}

The ancient practice of agriculture since its invention allowed ancient societies to discover the use of organic solid waste such as manure of livestock and poultry and food residues as fertilizer for soil in order to obtain better harvest. Those fertilizers are called compost, although today the compost is differentiated from bio-fertilizers which have a more sophisticated development process.

Compost is humus formed by a natural process of decomposition of organic waste of animal and vegetable origin; this humus can be obtained naturally or with the aid of empirical/scientific knowledge of the human being, by manipulating its process and application. The most natural compost is the one known as "ground for flowerpot", which is collected in opencast. Empirical composting is the use organic waste by a process carried out by man and based on empirical experience.

The compost production methods are varied as is the compost itself, there are manual and mechanical methods and there are combinations of both, there are opencast methods and methods according to the scale (small, medium, large). The materials used in the compost elaboration are mainly food and plants waste, feces, crop residues, wood through its degradation. In fact, compost is generated for different uses such as gardening, agriculture, soil regeneration, landfills, and gas generation. In the case of agriculture; compost can be produced for each plant variety.

In traditional and empirically methods, detritus are used, particularly cattle manure and bird guano. The generation of flies and insects, stenches and emission of methane gas are the main disadvantages of the application of manure. In the same way, manure generation is limited and it requires a larger surface to provide the nutrients needed for the development of food varieties.

The balanced compost resulting from the application of scientific knowledge, where mixtures of feces, wood, twigs and plant waste are prepared in appropriated propositions in order to obtain compost with nutrients needed particularly for agricultural products.

\section{A Model for Producing Compost}

In 2008 a multidisciplinary research group was integrated, the group is formed by agronomists, biologists, administrators and economists with the aim of carrying out a theoretical and practical research on composting for agricultural use.

With financial support from the Science and Technology Institute of the Federal District, a design and construction of a pilot composting plant was carried out. The plant was built in a facility belonging to the National Polytechnic Institute. The composting plant was designed with two plates of rectangular cement with a decline and a pit runoff at the lower edge (Figure 1). The purpose of this design is that the water used in irrigation and wetting of the organic material used can be drained into the pit and thus, the leachate captured can be processed in order to obtain a sub product for use as liquid fertilizer and pesticide.

The production chain was established in order to delimitate activities. Since the transportation of raw material, the construction of the piles until the control of the composting process with irrigation and leachate control. As part of the production process, activities to control humidity and temperature were also carried out.

Two piles were built (Figure 2), one designed for the borough Xochimilco and other for the borough of Milpa Alta. The stage related to the compost development lasted approximately six months. However, due to expe- 


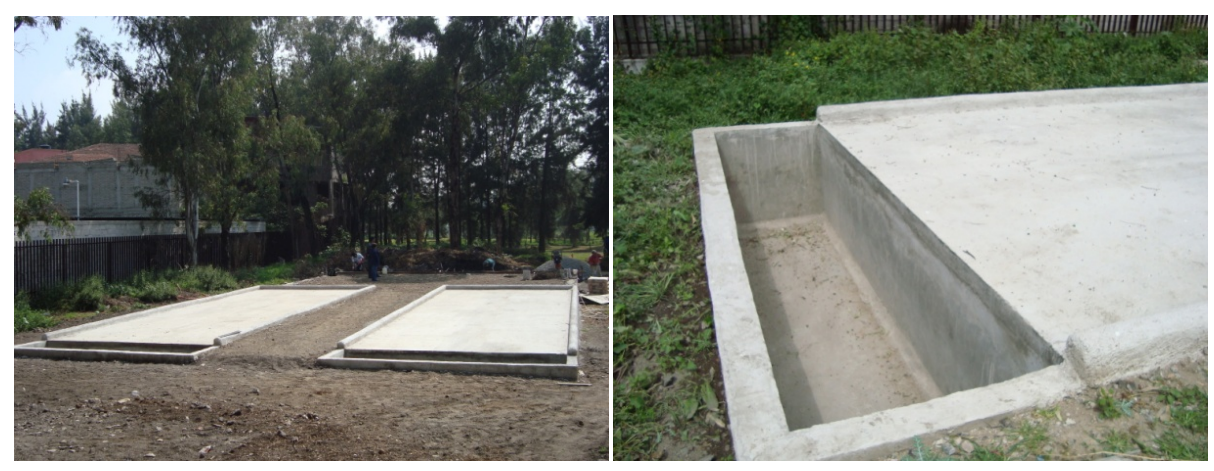

Figure 1. Concrete slabs and pits designed.

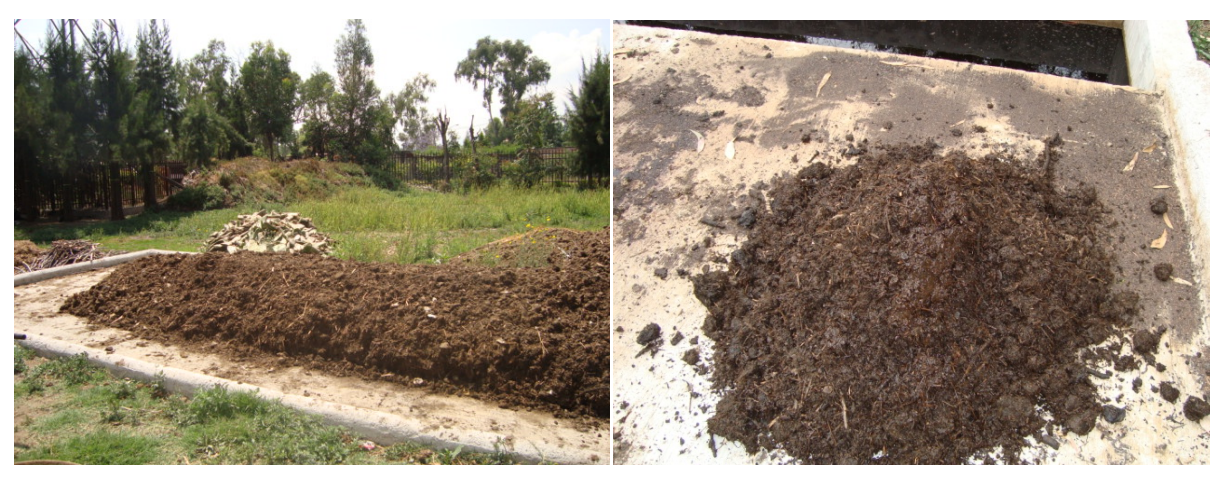

Figure 2. Organic material in windrow method of composting.

rience acquired, the length of the process can be reduced to four months.

Figure 3 illustrates the method used in the production process of compost.

The deposit of organic solid waste was carried out on the sides of the concrete piles, with this, the irrigation was facilitated. The control process was effectuated once a week in order to provide an accurate performance of the microorganism (Figure 4). The control of the temperature is a key factor within a composting process; therefore, the measure of such parameter was also accurately scheduled.

The behavior of the temperature during the composting process varied in ranges from $20^{\circ} \mathrm{C}$ up to $60^{\circ} \mathrm{C}$. It has to be mentioned that high temperatures can damages significantly the process due to the heat can kill the microorganisms.

In order to control the temperatures, the tumbling of the waste also irrigation must be carried out. During the composting process described in this paper, climate factors also influenced the process. Low climate temperatures as well as heavy rains impeded a temperature increase. In order to correct those adversities, a tunnel complex was designed and built to control the temperature and avoid climate changes (Figures 5, 6).

Once the compost matured, its temperature was stabilized, and unpleasant smells and methane emissions were controlled. The compost and the leachate were packing into especial containers. Hence, the application of the compos in crops of Nopal began (Figure 7).

Considering the aforementioned, it can be inferred that composting is a biotech where it can be possible to have control over the processes of biodegradation of organic matter. In a pile of material in composting, while fermentation processes occur at certain stages and under certain conditions, it is desirable the preservation of aerobic metabolisms trying to avoid anaerobic fermentation due to products obtained under this kind of metabolism are not suitable for agronomic application and lead to loss of nutrients. What matters is not just to biodegrade, but to operate under metabolic routes which enable the production of final products with quality [10].

In composting, three stages can be identified. The first stage is characterized by a fermentation process involving the actinomycetes bacteria and fungi, which are agents that initiate decomposition of organic waste by feeding. In this stage, temperature is raised from $20^{\circ} \mathrm{C}$ to $40^{\circ} \mathrm{C}$. The second stage, the decomposition agents are eaten by protozoan agents and beetle mites, temperatures range from $40^{\circ} \mathrm{C}$ to $60^{\circ} \mathrm{C}$. In the third stage the temperature drops and bugs and beetles replace the agents who acted in stages with at high temperatures [11]. 
Deposit of the solid waste

Transportation of organic waste

Disposal of waste in the concrete piles

Mix of waste and construction of waste piles

Irrigation, aeration of piles and monitoring of temperature

Maturation of compost and leachate, control of the process

Packing of compost and leachate into especial containers

Figure 3. Description of the composting process applied.

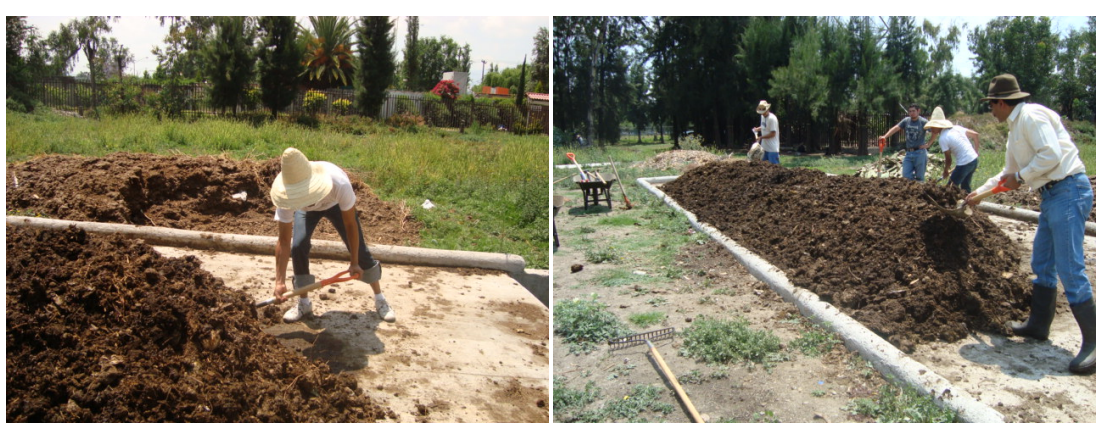

Figure 4. Processes of manual tumbling.

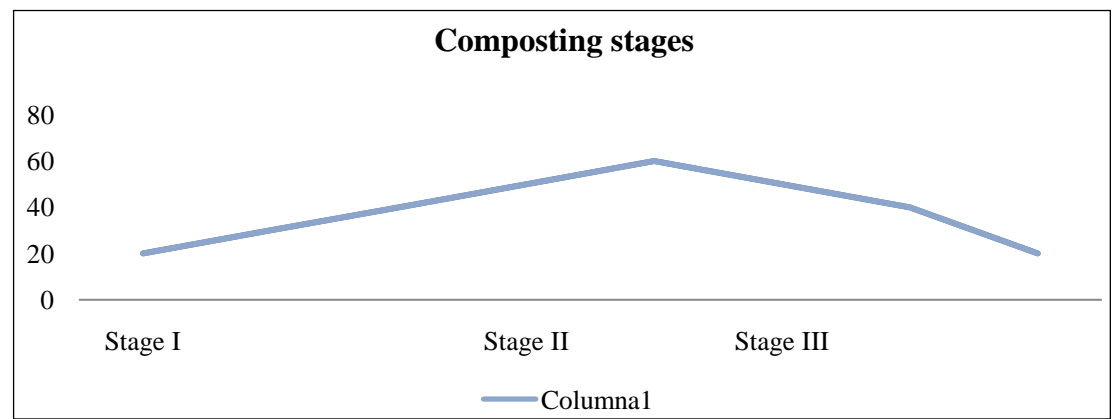

Figure 5. Temperature oscillation during composting process $\left({ }^{\circ} \mathrm{C}\right)$.
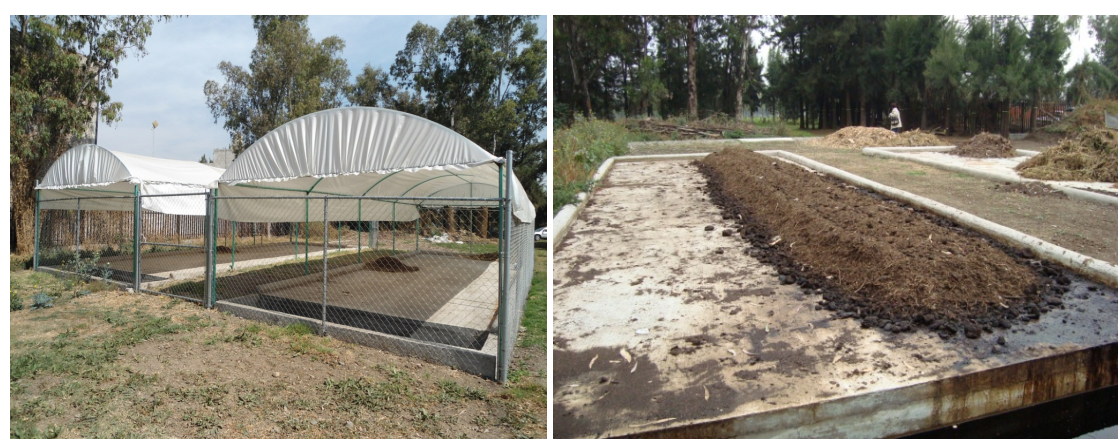

Figure 6. Tunnels to control weather and irritation process. 

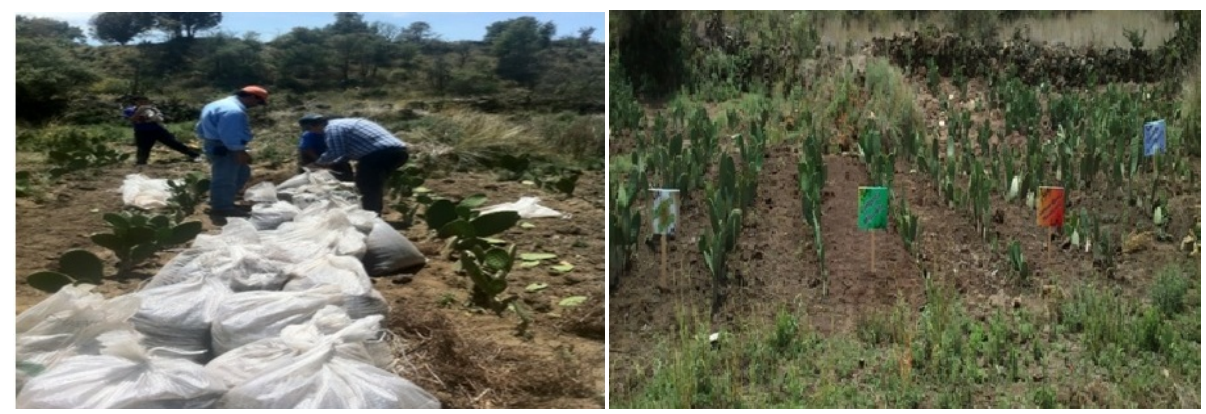

Figure 7. Packing and application of compost in crops.

The humus is the decomposition of the organic material to its simplest level. Such decomposition is a biological process mediated by fungi, bacteria, earthworms and some insects. These organisms break down organic matter to use it for their own metabolism, either to get energy for their biological processes through breathing or to incorporate it into their cellular structure. In this last case, carbon is finally added to the when these organisms die. In this way, carbon coming from the $\mathrm{CO}_{2}$ fixation during photosynthesis of plants is moved into the nature. The organisms involved in this cycle require adequate conditions to proliferate and thus play their role efficiently [12].

In a preliminary conclusion, it can be inferred that the compost has vastly superior benefits to the manure as fertilizer on crops. This statement is supported by the fact that manure shows multiple features that make it less manageable, as increased volume, and higher cost in transportation treatment than compost, it also represents environmental risks and pathogens. Also to ensure a harmless harvested crop with manure as fertilizer, manure required chemical and biological parameters well defined, situation that implies costly laboratory tests. Although compost also must be analyzed by laboratory tests to determine its harmlessness, its development process can be standardized, therefore, such tests can be avoided in subsequent processes, factor that does not happen with manure because it varies widely by several factors previously mentioned.

\section{Economic Analysis: Case of Study}

In order to develop a study focused on the economic feasibility of the use of compost over the use of manure, a case of study is presented. The community of San Lorenzo Tlacoyucan located in the borough of Milpa Alta served as a case of study to determinate the reduction of production costs in the cultivation of Nopal using compost instead of manure.

The borough of Milpa Alta, according to information from The Secretariat of Agriculture, Livestock, Rural Development, Fisheries and Food (in Spanish SAGARPA) presents a total of 4159 hectares in crop acres spread over 10 regions and among 9790 producers. In order to estimate the economic costs of production that involve the use of manure, the information aforementioned is used coupled with information gathered directly from the producers of the community of San Lorenzo Tlacoyucan. Based on data provided by the producers, the cost per ton of manure in 2013 ranges on average $\$ 4000.00^{2}$ and based on estimates made by the producers themselves, a ton of manure is sufficient to fertilize an area of $24 \mathrm{~m}^{2}$ in two years.

Therefore ${ }^{3}$ :

Total acreage $=4159$ ha $\left(41,590,000 \mathrm{~m}^{2}\right)$;

1 ton of manure $=24 \mathrm{~m}^{2}$ of fertilized area;

Manure cost $=\$ 4000.00$ per ton;

Manure freight cost $=\$ 1200.00$ per truck of $18 \mathrm{~m}^{3}$.

With information presented above, it is determined that, on average terms and for purposes of this analysis, the total amount of manure needed to cover the complete fertilization of the total cultivation area is 1,732,917

\footnotetext{
${ }^{2}$ The currency used for the whole analysis is the Mexican peso which as a reference on January 2014 the exchange rate is 13.3 per 1 US dollar.

${ }^{3}$ The analysis assumes general conditions in the growing areas of the region. However, it is taken into consideration that the characteristics of each zone vary among them and that factors such as soil properties, climatic conditions and geographic location of the terrain directly affect in times and crop yields, decreasing or increasing the use of fertilizers and the application of manure and thus modifying the behaviour of costs.
} 
tons, representing a total cost of $\$ 7047.25$ million (\$6931.67 million for the purchase +115.58 million for the freight).

For the community of San Lorenzo Tlacoyucan, the data would be:

Total acreage $=754$ ha $\left(7,540,000 \mathrm{~m}^{2}\right)$;

Total manure required $=314.167$ tons;

Total cost of manure $=\$ 1277.61$ ( $\$ 1256.67$ million for the purchase $+\$ 20.94$ million for the freight).

It must be clarified that the quantities calculated above do not integrate aspects different of the purchase and transport of manure. As indirect costs (treatment, storage, application, etc.) are not considered, though such costs may increase the production costs.

\section{Cost Analysis for Nopal Producers in Milpa Alta}

The compost has the following average prices according to the Secretariat of Agriculture, Livestock, Rural Development, Fisheries and Food (in Spanish SAGARPA): (Figure 8).

The price of the normal compost is defined in terms of the production costs aforementioned and incurred in the elaboration process. It should be pointed out that the market price of the compost may be even lower than the one shown in the table above and than the one used in the present analysis. The compost can be prepared for self-consumption by the producers themselves, so their sale price would be equal to its cost of production. It is necessary to make clear that the compost produced in the research presented is harmless compost and it was produced under a strict control of process in order to obtain organic fertilizer for crops with specific characteristics for nopal. In the same way, the production would be on-site; therefore, there would not be transportation costs.

After making such clarifications, the calculation of the costs for the use of compost is done assuming general conditions and taking into consideration estimates collected in practice and fieldwork:

Total acreage $=4159$ ha $\left(41,590,000 \mathrm{~m}^{2}\right)$;

1 ton of compost $=12 \mathrm{~m}^{2}$ of fertilized area;

Composting cost $=\$ 1500.00$ per ton;

Total demand of compost $=3,465,833$ tons;

Total cost $=\$ 5198.75$ million .

For the community of San Lorenzo Tlacoyucan:

Total acreage $=754$ ha $\left(7,540,000 \mathrm{~m}^{2}\right)$;

Compost required $=628,333$ ton;

Total cost of the compost $=\$ 942.50$ million.

The information presented can be analyzed in the Figure 9 below, where it is possible to see that the total difference between the cost of manure and compost for the total acreage of the borough of Mila Alta implies a reduction of $\$ 1845.5$ million which represents a saving of $26.20 \%$ over the total cost of manure, equally, in terms of the community of San Lorenzo Tlacoyucan, there is a difference of $\$ 335.11$ million, which implies a cost reduction of the same percentage (26.20\%).

The previous information must integrate different considerations. The borough of Milpa Alta currently operates a grant program to purchase and transport manure. The subsidy provided is $\$ 12,000$ per producer for the fertilization of $60 \mathrm{~m}^{2}$. The grant program has an annual cap of $\$ 60$ million, so 30 acres can be covered.

Applying a sensitivity analysis in the calculations, considering the subsidy provided by the borough the total cost of manure for the region is \$6996.94 million, amount which is even higher compared to $\$ 5198.75$ million of the total cost of the compost. The difference would be reduced to $\$ 1798.19$ million representing a saving of $25.69 \%$. With this, it can be inferred that use of compost still represents a considerable decrease in the cost of production, even with the subsidy program for the manure. Another key aspect for the compost is the fact that its use and therefore its impact on the production costs of nopal crops will be diminished in subsequent production cycles. Production quantities required are diminished given the characteristic of soil enrichment. Compost production processes in future crops will work as a strain. This feature would enable the generation of a phenotypic variant that involves the conservation of the defining qualities in the composition and enrichment of nutrients in agricultural soils. Thus the volume of compost needed to fertilize the plots, would gradually and equally decrease the cost of production.

Finally, compost is a feasible option for fertilizing nopal crops given the controlled characteristics of the ela- 


\begin{tabular}{|l|c|c|}
\hline \multicolumn{1}{|c|}{ Product } & Price & Unit \\
\hline Compost & $\$ 1500.00$ & Ton \\
\hline Vermicompost & $\$ 2000.00$ & Ton \\
\hline Bokashi Compost & $\$ 1500.00$ & Ton \\
\hline Liquid fertilizer & $\$ 120.00$ & Litre \\
\hline
\end{tabular}

Figure 8. Prices of organic fertilizer in Mexican Pesos fixed by SAGARPA.

\begin{tabular}{|c|l|c|c|} 
& & Manure & Compost \\
\hline & Average cost per ton & $\$ 4067.00^{*}$ & $\$ 1500.00$ \\
\hline Milpa Alta & Total demand (tonnes) & $1,732,917$ & $3,465,833$ \\
\cline { 2 - 4 } & Total cost (millions of Mexican pesos) & $\$ 7047.25$ & $\$ 5198.75$ \\
\hline $\begin{array}{c}\text { San } \\
\text { Lorenzo }\end{array}$ & Total demand (tonnes) & 314,167 & 628,333 \\
\hline & Total cost (millions of Mexican pesos) & $\$ 1277.61$ & $\$ 942.50$ \\
\hline
\end{tabular}

Figure 9. Differentiation of costs of manure and compost and total costs of production using different fertilizers.

boration process. Fresh manure may have some advantages in its use, but in a comparative analysis against the use of compost, benefits of compost overcome the use of manure, and the disadvantages of its use and application are minimal. The use of manure has serious environmental effects, not just GHG generation, soil damage and contamination of the crop itself, which, because as nopal is a food product, the contamination represents a serious public health risks. On the other hand, compost is a harmless and organic fertilizer whose production is focused on increasing yields and improving properties of soil nutrients. As demonstrated economically, the production cost is significantly reduced through the use of compost, and likewise, its production is biologically and economically feasible for the needs of nopal producers from Milpa Alta.

\section{Model of Organic Agriculture and Development Strategy}

One of the guiding principles since the beginning of the project is to design an agricultural model of small-scale that can integrate the use of organic inputs in the cultivation of various agricultural products. The nopal was selected due to it is a crop in which the main research lines are based on.

Nopal is a plant genus of cacti, belongs to the genus Opuntia and there are a lot of varieties in Mexico, the National Commission for Knowledge and Use of Biodiversity (in Spanish CONABIO) has identified 285 varieties across the country which can be opuntia for human consumption.

Nopal is a plant that requires relatively little water, is highly resistant to the weather, it is produced in soils with poor amount of nutrients, it withstands extreme temperature variations, it has acceptable food quality, and it has been part of the diet of native ethnic groups. Its cultivation can be done by small producers who besides of generating their own food, can generate surpluses for the market and derive an agribusiness in small and medium scale, therefore, they generate employment and raise their income.

The elements to build the model of organic farming are: technological innovation with the design and construction of bio-tunnels for small surfaces; the development of bio-insecticides and fertilizers and their application in plant cultivation; training of manpower; climate monitoring; harvesting and storage of the product; local, regional and national or international marketing; agro-industrial development with the diversification of consumption of the product (Figure 10). In any case, the financing, management and recovery must be considered.

The objectives are to increase or maintain the surface yields, reduce costs, generate quality and competitive prices on the product, raise incomes, employment and improvement of the technical capacity of the producers. This set of objectives necessarily involves the contribution to preserve and improve the environment in the communities.

Nopal cultivation can be also used to improve the soil, recycle organic solid waste, retain and conserve soil moisture, help the animal consumption to save the use of water in small livestock and cattle, protect the crop against other varieties of products using the nopal itself to produce fruit and to help control noxious weeds. 


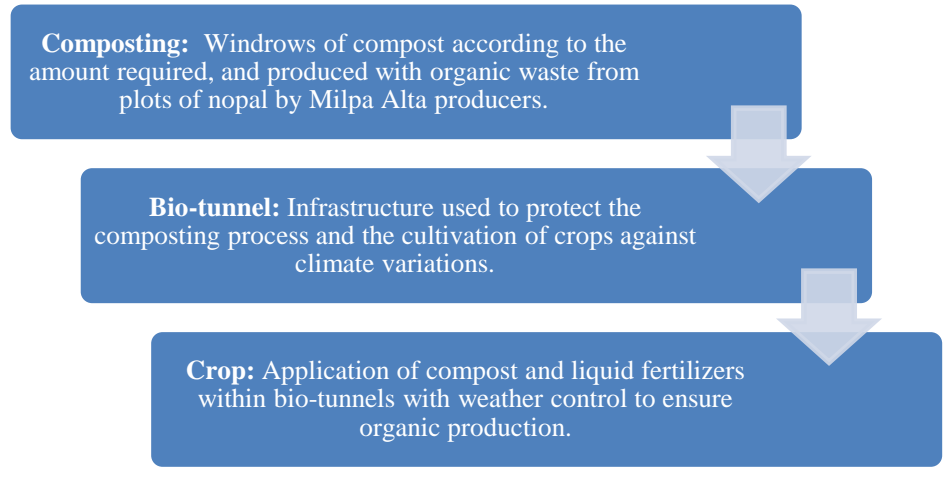

Figure 10. Chain of organic production of nopal with compost as fertilizer.

\section{Conclusions}

In a local, regional or national context, the development triad is the combination of technical innovation, funding and market. These basics elements have to be accompanied by three additional aspects: innovation in training, funding of the application and resource recovery, and the market for commercialization. In the same way, the combination of these elements has to be done by an individual or collective entrepreneur, in the case of small-scale production in bio-tunnels and using organic inputs may be rural families or cooperatives of production and marketing by themselves.

The implementation of the model of organic farming in bio-tunnels for small scale is the result of the combination of internal and external factors. External factors can be public/private to provide communities with the elements, but the involvement of the community is essential in order to organize, lead and sustain the model and thus it can transform the community in an economic and social way by helping solve the most acute problems, such as marginalization, employment, income levels, quality of life and poverty.

Unlike many development projects, which end up failing after having been undertaken, the aim of the project is that the rural community becomes the central subject of development and growth of the town and the region, and of course, this strategy is not foolproof. Adverse factors can appear which can impede the community to auto-promote the generation of its own wealth, either inside or outside the community. Such factors can generally be political and cultural, but can also be economic if internal or external interest of hoarding natural resources appears.

Production and marketing of nopal can be a way to structure development and growing projects among the communities. In the community of Milpa Alta, there is already a long period of production of nopal and the community specializes in growing, however, farmers do not have the same conditions, and it is necessary to improve production conditions and develop the commercialization among small producers in order to generate competitiveness and thus to increase the area of sales beyond the current market.

In other communities, the project should start from scratch, as in the case of the municipalities of San José del Rincón and Villa Victoria in the State of Mexico, which have been characterized by high marginalization. Mazahua communities live in such municipalities and were provided by NGOs with elements to undertake nopal growing in greenhouse. The initiative started with 15 greenhouses to be extended to a total of 85, generating more than 50 tons per year and benefiting more than 2000 members of these communities.

Production scales may vary and can range from 50 meters to 500 meters. It is necessary to undertake a finer study to define the optimal scale which generates production with costs and competitive prices. The combination of organic inputs in the cultivation of plants with bio-tunnels can help homogenize yields per surface and increase the number of crops per year.

In other words, the model aims to generate productive human resources from community organizational forms, in order to take advantage of the own endowment of natural resources and use them to generate wealth for communities. In the same way, it is sought to abandon marginalization and poverty and eliminate predatory practices within the community and the surrounding environment.

\section{References}

[1] Levetin, E. and McMahon, K. (2008) Origins of Agriculture. Plants and Society. 5th Edition, McGraw-Hill, New York. 
[2] Squires, V. (2009) Historical Origins of Agriculture. The Role of Food, Agriculture, Forestry and Fisheries in Human Nutrition: Volume 4. EOLSS Publishers Co Ltd., Oxford.

[3] Shirani, H., Hajabbasi, M.A., Afyuni, M. and Hemmat, A. (2002) Effects of Farmyard Manure and Tillage Systems on Soil Physical Properties and Corn Yield in Central Iran. Soil and Tillage Research, 68, 101-108. http://dx.doi.org/10.1016/S0167-1987(02)00110-1

[4] Bierman, P.M. and Rosen, C.J. (2005) Nutrient Cycling and Maintaining Soil Fertility. Journal of Nutrient Management for Vegetable, Fruit \& Nut Crops, The University of Minnesota, 10-11.

[5] Rahman, S. and Wiederholt, R. (2012) Options for Land Application of Solid Manure. North Dakota State University, Fargo.

[6] Harris, F. and Yusuf, M.A. (2001) Manure Management by Smallholder Farmers in the Kano Close-Settled Zone, Nigeria. Experimental Agriculture, 37, 319-332. http://dx.doi.org/10.1017/S0014479701003040

[7] Weill, A.E. and McKyes, G. (1989) Agronomic and Economic Feasibility of Growing Corn under Reduced Tillage and Inorganic or Organic Fertilizer in Quebec. Soil \& Tillage Research, 14, 311-315. http://dx.doi.org/10.1016/0167-1987(89)90052-4

[8] Rodríguez, M. and Córdovaa, A. (2006) Manual de Compostaje Municipal. Tratamiento de Residuos Sólidos Urbanos. Secretaría de Medio Ambiente y Recursos Naturales, Instituto Nacional de Ecología, Deutsche Gesellschaft für Technische Zusammenarbeit.

[9] NEOINFORMATION (2003) Perspectiva Ambiental-Compostaje. http://www.scribd.com/doc/30411551/PERSPECTIVA-AMBIENTAL-Compostaje

[10] Escamilla, P., Tavera, M.E. and Villanueva, S. (2011) Factibilidad tecnológica para la producción de composta en el DF. Chapter 1. Instituto Politecnico Nacional, Mexico.

[11] Salinas, E. (2011) Factibilidad tecnológica para la producción de composta en el DF. Chapter 3. Instituto Politecnico Nacional, Mexico.

[12] Alvarado, H. (2011) Factibilidad tecnológica para la producción de composta en el DF. Chapter 2. Instituto Politecnico Nacional, Mexico. 